\title{
KARAKTERISTIK SOSIAL EKONOMI YANG MEMPENGARUHI PENDAPATAN RUMAH TANGGA PENYADAP GETAH PINUS DI DESA SOMAGEDE, KEBUMEN, JAWA TENGAH
}

(Socio-economic Characteristics Affecting Household Income of Pine Gum Taper: Case study in Somagede, Kebumen, and Central Java)

\author{
Oleh/By: \\ S. Andy Cahyono, Nur Ainun Jariyah dan (and) Yonky Indrajaya
}

\begin{abstract}
The increase of household income determines the family welfare. Some socioeconomic characteristics of the household affecting the income of pine gum taper are explored in this study.

The objective of this research is to learn the social economic characteristics affecting the pine gum taper. The method of this research was simple random sampling with 30 respondents. Data were analyzed by multiple linear regression which use social economic characteristics as the dependent variable and household income as the independent variable.

The result of this research indicates that socio-economic characteristics affect the income of pine gum taper. The income of pine gum taper was affected significantly by the income of non-tapping activity, stand ages, \& pine productivity. The household income can be improved by increasing income outside pine taping and improving pine productivity.

This research recommends that to improve the pine gum taper household income, some activities such as diversifying income outside pine gum taping and improving pine productivity are needed.
\end{abstract}

Key words: activities, stand ages, pine productivity, income of non-taping.

\begin{abstract}
Abstrak
Peningkatan pendapatan rumah tangga menentukan tingkat kesejahteraan keluarga dan karakteristik sosial ekonomi rumah tangga mempengaruhi pendapatan rumah tangga penyadap getah pinus.

Penelitian ini bertujuan mempelajari karakteristik sosial ekonomi yang mempengaruhi pendapatan rumah tangga penyadap pinus. Metode survey dipergunakan pada penelitian ini dengan penarikan sampel menggunakan metode simple random sampling pada 30 orang petani responden. Analisis data menggunakan persamaan regresi linier berganda pada peubah karakteristik sosial ekonomi yang diduga mempengaruhi pendapatan rumah tangga.

Hasil kajian menunjukkan bahwa karakteristik sosial ekonomi mempengaruhi pendapatan rumah tangga petani penyadap getah pinus. Pendapatan rumah tangga petani penyadap getah pinus dipengaruhi nyata secara statistik oleh pendapatan dari
\end{abstract}


luargetah pinus, umur pinus, dan produksi getah pinus. Pendapatan rumah tangga dapat ditingkatkan dengan meningkatkan pendapatan di luar sadap pinus dan peningkatan produktivitas pinus. Penelitian ini merekomendasikan bahwa peningkatan pendapatan rumah tangga penyadap dilakukan dengan diversifikasi pendapatan di luar pinus dan peningkatan produktivitas getah.

Kata kunci: kegiatan, umur tegakan, produktivitas pinus, pendapatan di luar penyadapan

\section{PENDAHULUAN}

\section{Latar Belakang}

Pada mulanya penanaman pinus di lahan hutan, terutama jenis Pinus merkusii Jungh et.de.Vries, bertujuan untuk mempercepat reboisasi dan rehabilitasi lahan kosong dalam kawasan hutan (Jariah, 1998). Secara teknis penanaman, pemilihan ini cukup tepat karena pinus merupakan jenis pionir yang mampu bertahan hidup dan pertumbuhannya sangat cepat (fast growing species) dan mampu tumbuh pada kondisi sulit. Selain hasil kayu, pinus menghasilkan getah untuk diolah menjadi gondorukem dan terpentin. Prospek ekonomi pinus cukup baik karena pinus dapat dipergunakan sebagai bahan baku industri kayu lapis, kertas, korek api, dan lain sebagainya.

Pendapatan rumah tangga di pedesaan pada umumnya tidak berasal dari satu sumber, tetapi berasal dari dua atau lebih sumber pendapatan. Ragam sumber pendapatan tersebut diduga dipengaruhi oleh tingkat pendapatan itu sendiri. Tingkat pendapatan yang relatif rendah mengharuskan anggota rumah tangga untuk lebih giat bekerja. Bagi sebagian rumah tangga, upaya tersebut tidak hanya menambah curahan jam kerja tetapi juga melakukan kegiatan-kegiatan lainnya. 
Menurut Tirtakusuma (1978), usaha penduduk sekitar hutan dapat dikelompokkan menjadi 3 yaitu: (1) petani asli yang tidak pernah mencari hasil lain, selain pertanian, berkebun atau beternak. (2) tenaga kerja tetap yang orientasinya mencari hasil hutan seperti penyadap getah pinus, petani hutan, mencari rencek, mencari rotan dan sebagainya. (3) Tenaga kerja tidak tetap, hanya bekerja pada pekerjaan yang menguntungkan dan memuaskan perasaan antara lain buruh gudang, buruh tani hutan, mengambil rencek dan lain-lain.

Karakteristik sosial ekonomi petani sekitar hutan berbeda dengan masyarakat lain, terutama untuk petani yang berada di sekitar hutan pinus. Seperti Perum Perhutani, telah mempergunakan tenaga petani untuk melakukan penyadapan getah pinus. Selain bertujuan untuk meningkatkan pendapatan petani, hal tersebut merupakan alah satu cara Perum Perhutani untuk melakukan pemeliharaan hutan dengan melibatkan petani atau masyarakat sekitar hutan. Oleh karena itu, diperlukan suatu kajian untuk mengetahui karakteristik sosial ekonomi yang mempengaruhi pendapatan rumah tangga petani penyadap getah pinus.

\section{Tujuan}

Penelitian ini bertujuan untuk mempelajari karakteristik sosial ekonomi yang mempengaruhi pendapatan rumah tangga petani penyadap getah pinus. Luaran yang diharapkan adalah diperolehnya faktor sosial ekonomi untuk meningkatkan pendapatan rumah tangga penyadap pinus 


\section{METODE PENELITIAN}

\section{Lokasi}

Penelitian dilaksanakan di Desa Somagede, Kecamatan Sempor, Kabupaten Kebumen. Secara administrasi kehutanan, lokasi penelitian terletak di RPH Somagede, BKPH Karanganyar, KPH Kedu Selatan, Perum Perhutani Unit I Jawa Tengah.

\section{Pengambilan Sampel dan Pengumpulan Data}

Responden penelitian adalah petani penyadap getah pinus yang dipilih dengan menggunakan metode penarikan contoh simple random sampling. Jumlah sampel penelitian yang diambil berjumlah 30 orang (11\%) dari 269 penyadap. Pengumpulan data primer dengan wawancara berdasarkan daftar pertanyaan yang telah disiapkan. Data sekunder diperoleh dari instansi yang terkait dengan kajian ini.

\section{Analisis Data}

Untuk mempelajari karakteristik sosial ekonomi petani yang mempengaruhi pendapatan rumah tangga dipergunakan analisis linier berganda dengan menggunakan metode OLS (Ordinary least square). Penggunaan metode ini berdasarkan pertimbangan bahwa analisis regresi merupakan metode statistik yang dipergunakan untuk menentukan kemungkinan bentuk hubungan antara variabelvariabel dan tujuannya adalah untuk memperkirakan nilai dari suatu variabel dalam hubungannya dengan variabel yang diketahui. Hubungan beberapa karakteristik 
sosial ekonomi rumah tangga petani dengan pendapatan secara matematis dirumuskan sebagai berikut.

$Y_{i}=\beta_{0}+\beta_{1} X_{1 i}+\beta_{2} X_{2 i}+\beta_{3} X_{3 i}+\beta_{4} X_{4 i}+\beta_{5} X_{5 i}+\beta_{6} X_{6 i}+u$

Keterangan:

$\mathrm{Y}_{\mathrm{i}} \quad=$ Pendapatan rumah tangga $(\mathrm{Rp})$

$\mathrm{X}_{1 \mathrm{i}} \quad=$ Umur kepala rumah tangga $(\mathrm{Th})$

$\mathrm{X}_{2 \mathrm{i}} \quad=$ Kontribusi pendapatan diluar getah pinus (\%)

$\mathrm{X}_{3 \mathrm{i}} \quad=$ Jumlah anggota keluarga (orang)

$\mathrm{X}_{4 \mathrm{i}} \quad=$ Luas lahan $(\mathrm{Ha})$

$\mathrm{X}_{5 \mathrm{i}} \quad=$ Usia pohon pinus $(\mathrm{Th})$

$\mathrm{X}_{6 \mathrm{i}} \quad=$ Getah pinus yang dihasilkan oleh penyadap (Kg/tahun)

$\beta_{\mathrm{i}} \quad=$ Koefisien regresi

$\mathrm{u} \quad=$ disturbance error

Pengujian terhadap parameter regresi dilakukan secara tunggal dan bersamasama. Pengujian secara tunggal dengan menggunakan uji t-student. Adapun pengujian secara bersama-sama dengan mengunakan uji $\mathrm{F}$ (Gujarati, 1979).

\section{HASIL DAN PEMBAHASAN}

\subsection{Karakteristik Sosial Ekonomi Rumah Tangga Penyadap Getah Pinus}

Karakteristik sosial ekonomi responden merupakan sifat yang melekat pada individu petani penyadap getah pinus. Karakteristik tersebut akan mempengaruhi kondisi sosial ekonomi dan pengambilan keputusan dalam rumah tangga. Pencandraan karakteristik sosial ekonomi disajikan pada Tabel 1. 
Tabel 1. Karakteristik sosial ekonomi responden

Table 1. Social economic characteristic respondent

\begin{tabular}{|l|l|l|c|c|c|}
\hline No & \multicolumn{1}{|c|}{ Uraian (Descriptions) } & \multicolumn{1}{|c|}{$\begin{array}{c}\text { Satuan } \\
\text { (set of) }\end{array}$} & $\begin{array}{c}\text { Maksimum } \\
\text { (maximum) }\end{array}$ & $\begin{array}{c}\text { Minimum } \\
\text { (minimum) }\end{array}$ & $\begin{array}{c}\text { Rata-rata } \\
\text { (mean) }\end{array}$ \\
\hline 1. & $\begin{array}{l}\text { Usia responden /Age of } \\
\text { respondent }\end{array}$ & Tahun/year & 61,0 & 26,0 & 42 \\
\hline 2. & $\begin{array}{l}\text { Tanggungan } \\
\text { keluarga/family burden }\end{array}$ & Orang/peolpe & 7,0 & 2,0 & 4 \\
\hline 3. & $\begin{array}{l}\text { Kepemilikan } \\
\text { lahan/ownership offarm }\end{array}$ & Ha/Hectare & 2,5 & 0,035 & 0,68 \\
\hline 4. & Umur pinus/age of pine & Tahun/year & 18,0 & 15,0 & 15,76 \\
\hline 5. & $\begin{array}{l}\text { Umur pinus pertama kali } \\
\text { sadap/ Pine age taped at } \\
\text { first time }\end{array}$ & Tahun/year & 12,0 & 7,0 & 10,45 \\
\hline 6. & $\begin{array}{l}\text { Jumlah pohon pinus/ } \\
\text { amount of pine tree }\end{array}$ & Pohon/ tree & 2.000 & 0 & 763 \\
\hline 7. & $\begin{array}{l}\text { Getah pinus yang } \\
\text { dihasilkan oleh penyadap/ } \\
\text { pine gum production }\end{array}$ & $\mathrm{Kg}$ & 6.000 & 0 & 2.612 \\
\hline 8. & $\begin{array}{l}\text { Pendapatan dari sadap } \\
\text { pinus/ income from pine } \\
\text { tapping }\end{array}$ & $\mathrm{Rp}$ & 5.070 .000 & 0 & 2.144 .700 \\
\hline 9. & $\begin{array}{l}\text { Pendapatan di luar sadap } \\
\text { pinus/ income of non pine } \\
\text { tapping }\end{array}$ & $\mathrm{Rp}$ & 6.420 .000 & 85.000 & 1.764 .300 \\
\hline 10. & $\begin{array}{l}\text { Pendapatan total/ total } \\
\text { income }\end{array}$ & $\mathrm{Rp}$ & 800.000 & 3.924 .700 \\
\hline
\end{tabular}

Tabel 1 menunjukkan bahwa rata-rata penyadap getah pinus di Desa Somagede berusia produktif (rata-rata berusia 42 tahun). Hal ini akan mempengaruhi produktivitas penyadapan getah pinus dan pendapatan yang akan diterima. Tanggungan keluarga berkisar antara 2 sampai dengan 7 orang. Kepemilikan lahan rata-rata seluas 0,68 ha. Dengan kondisi ini, maka keluarga yang memiliki tanggungan keluarga banyak akan semakin besar beban hidup yang ditanggungnya, apalagi bila hal tersebut disertai dengan keterbatasan sumberdaya yang dapat diakses. 
Umur pohon pinus rata-rata telah berusia 15 tahun dengan saat pertama kali disadap pada usia 10-11 tahun. Namun ada beberapa pohon yang disadap oleh petani pada saat pohon pinus berusia 7 tahun. Hal ini dilakukan untuk meningkatkan produksi getah yang mereka peroleh.

Produksi rata-rata getah pinus yang diperoleh setiap penyadap sebesar 2.612 $\mathrm{kg}$ dengan pendapatan rata-rata per penyadap sebesar Rp2.144.700 per tahun. Pendapatan yang relatif besar ini dapat diandalkan untuk memenuhi kebutuhan keluarga. Pada tahun 1975, saat tanaman pohon pinus di tanam, masyarakat sekitar hutan cukup skeptis dengan hutan pinus. Hal ini terlihat dari keenganan mereka untuk dijadikan sebagai tenaga kerja penyadap getah pinus. Pada saat itu Perhutani tidak mengalami kesulitan untuk membagi pohon pinus di antara penyadap. Perkembangan lebih lanjut menunjukkan bahwa prospek kegiatan penyadapan getah pinus mampu memberikan pendapatan yang relatif tinggi. Apabila dahulu pekerjaan penyadapan getah pinus merupakan pekerjaan sambilan, namun saat ini pekerjaan tersebut telah menjadi pekerjaan sambilan utama bahkan pokok. Kondisi ini menunjukkan telah terjadinya pergeseran persepsi dalam memandang manfaat yang dapat diperoleh dari hutan pinus. Hasil hutan non kayu berupa getah pinus telah dapat memberikan manfaat ekonomi secara positif bagi peningkatan kesejahteraan keluarga petani di sekitar hutan pinus.

Pohon pinus yang disadap kira-kira berumur 11 tahun dengan garis tengah 21 cm (Annonim, 1997). Selain kegiatan penyadapan getah pinus, para petani tersebut mengisi waktunya dengan bertani atau berladang. Namun demikian, hasil yang diperoleh seringkali lebih kecil dibandingkan dengan menyadap getah pinus. Hal ini 
dikarenakan lahan yang diusahakan umumnya relatif sempit dengan produktivitas yang rendah. Produksi hasil pertanian tersebut hanya cukup untuk memenuhi kebutuhan subsisten petani terutama pada masa-masa sulit.

\subsection{Faktor-Faktor yang Mempengaruhi Pendapatan Rumah Tangga Penyadap}

Karakteristik sosial ekonomi rumah tangga penyadap getah pinus yang diduga mempengaruhi tingkat pendapatan rumah tangga $(\mathrm{Y})$ adalah umur $\left(\mathrm{X}_{1}\right)$, kontribusi pendapatan diluar getah pinus $\left(\mathrm{X}_{2}\right)$, jumlah anggota keluarga $\left(\mathrm{X}_{3}\right)$, luas lahan $\left(\mathrm{X}_{4}\right)$, usia pohon pinus $\left(\mathrm{X}_{5}\right)$, dan produksi getah pinus $\left(\mathrm{X}_{6}\right)$. Persamaan regresi yang diperoleh adalah:

$$
\begin{aligned}
& Y=-4931502+12467 X_{1}+6926821 X_{2}-1776,383569 X_{3}-306365 X_{4}+ \\
& 157769 X_{5}+1215,731412 X_{6}
\end{aligned}
$$

Hasil analisis regresi yang tersaji pada Tabel 2. menunjukkan bahwa variabel yang diduga mempengaruhi pendapatan rumah tangga ternyata secara bersama-sama mempengaruhi pendapatan rumah tangga. Hal ini ditunjukkan dari besarnya nilai $\mathrm{F}$ hitung yang signifikan dengan tingkat kepercayaan 99\%.

Tabel 2. Analisis varian faktor yang mempengaruhi pendapatan rumahtangga

Table 2. Analysis variant factor influencing household income

\begin{tabular}{|l|r|c|c|c|}
\hline $\begin{array}{l}\text { Sumber } \\
\text { source })\end{array}$ & DF & $\begin{array}{l}\text { Jumlah Kuadrat } \\
\text { (sum of squares })\end{array}$ & $\begin{array}{l}\text { Kuadrat tengah } \\
\text { (mean squares })\end{array}$ & $\begin{array}{l}\text { F-hitung } \\
\text { (F value })\end{array}$ \\
\hline Model & 6 & $5,4981309 \times 10^{13}$ & $9,1635514 \times 10^{12}$ & $16,864 * * *$ \\
\hline Error & 23 & $1,2497585 \times 10^{13}$ & $5,4337327 \times 10^{11}$ & \\
\hline Total & 29 & $6,7478894 \times 10^{13}$ & & \\
\hline
\end{tabular}

Keterangan (Remark):

*** = Nyata pada tingkat kepercayaan 99\% (Significant at level 99\%) 
Hasil analisis regresi terhadap peubah karakteristik sosial ekonomi yang mempengaruhi pendapatan petani penyadap getah pinus disajikan pada Tabel 3. Pada Tabel 3, koefesien determinan sebesar 0,7665 yang artinya 76,65\% keragaman pada pendapatan rumah tangga petani penyadap getah pinus dapat dijelaskan oleh variabelvariabel yang dimasukkan ke dalam model. Adapun sisanya sebesar 23,35\% lainnya dijelaskan oleh variabel lain yang belum dimasukkan ke dalam model regresi.

Tabel 3. Koefesien regresi karakteristik sosial ekonomi yang mempengaruhi pendapatan rumah tangga penyadap getah pinus

Table 3. Parameter estimate of social economic characteristic influencing household income

\begin{tabular}{|l|c|c|c|}
\hline Variabel / variable & $\begin{array}{l}\text { Koefesien Regresi } \\
\text { (parameter } \\
\text { estimate }\end{array}$ & $\begin{array}{l}\text { Simpangan Baku } \\
\text { (standard error })\end{array}$ & $\begin{array}{l}\text { t-hitung } \\
\text { ( value })\end{array}$ \\
\hline Intersep/ intersept & -4931502 & 1122770,7571 & 0,549 \\
\hline $\begin{array}{l}\text { Umur Penyadap/ age } \\
\text { taper }\end{array}$ & 12467 & 22689,355835 & $7,998 * * *$ \\
\hline $\begin{array}{l}\text { Kont Pend luar pinus/ } \\
\text { Non income pine } \\
\text { contribution }\end{array}$ & 6926821 & 866090,05893 & $-0,011$ \\
\hline $\begin{array}{l}\text { Anggota keluarga/ } \\
\text { amount offamily }\end{array}$ & $-1776,383569$ & 157176,16407 & $-1,090$ \\
\hline $\begin{array}{l}\text { Luas lahan / area } \\
\text { farm }\end{array}$ & -306365 & 280995,93643 & $2,783^{* * *}$ \\
\hline $\begin{array}{l}\text { Umur pinus/ age of } \\
\text { pine }\end{array}$ & 157769 & 56698,606050 & $8,024 * * *$ \\
\hline $\begin{array}{l}\text { Produksi getah pinus/ } \\
\text { pine productivity }\end{array}$ & 1215,731412 & 151,50477101 & \\
\hline & $=16,864 * * *$ & & \\
\hline F-hitung/ F value & $=0,7665$ & & \\
\hline $\mathrm{R}^{2}$ adj & & & \\
\hline
\end{tabular}

Keterangan (Remark):

$* * * \quad=$ Nyata pada tingkat kepercayaan $99 \%$ (Significant at level 99\%)

** = Nyata pada tingkat kepercayaan 95\% (Significant at level 95\%)

* $\quad=$ Nyata pada tingkat kepercayaan $80 \%$ (Significant at level 80\%) 
Selanjutnya, pengujian secara parsial dengan uji t-student diperoleh hasil bahwa hanya variabel kontribusi pendapatan di luar pinus, umur pohon pinus, dan produksi getah pinus yang berpengaruh nyata terhadap pendapatan rumah tangga penyadap getah pinus. Adapun variabel lainnya tidak secara nyata mempengaruhi tingkat pendapatan rumah tangga.

Kontribusi pendapatan di luar getah pinus berpengaruh nyata terhadap pendapatan total rumah tangga. Semakin besar kontribusi pendapatan dari luar getah pinus, maka akan semakin besar pula pendapatan total rumah tangga. Kondisi ini menunjukkan bahwa pekerjaan-pekerjaan di luar menyadap pinus memiliki potensi yang besar untuk meningkatkan pendapatan rumah tangga. Semakin besar kontribusi pendapatan dari luar kegiatan penyadapan getah pinus maka pendapatan total rumah tangga akan semakin besar pula. Pengamatan dilapangan menunjukkan bahwa para penyadap getah pinus sebagian besar mengandalkan pendapatan keluarganya dari usaha menyadap getah pinus. Pekerjaan-pekerjaan di luar menyadap getah pinus dijadikan sebagai tambahan penghasilan. Sehingga peningkatan pendapatan yang berasal dari luar penyadapan getah pinus akan memberikan dampak besar terhadap peningkatan pendapatan total rumah tangga. Kondisi ini dikarenakan peningkatan pendapatan dari penyadapan getah pinus hanya dapat ditingkatkan dengan peningkatan produktivitas sadap dan itupun terbatas pada kemampuan pohon pinus.

Usia pohon pinus berpengaruh positif secara nyata mempengaruhi tingkat pendapatan rumah tangga. Semakin tua pohon pinus maka akan semakin besar pula pendapatan yang diterimanya. Peningkatan umur pinus sebesar 1 tahun akan meningkatkan pendapatan rumah tangga sebesar Rp157.769,-. 
Produksi getah pinus yang dihasilkan oleh penyadap berpengaruh positif secara nyata terhadap pendapatan rumah tangga penyadap getah pinus. Semakin tinggi produksi getah pinus yang diperoleh, maka pendapatan rumah tangga akan semakin meningkat. Penambahan produksi getah pinus yang disadap sebesar $1 \mathrm{~kg}$ akan mengakibatkan peningkatan pendapatan sebesar Rp 1.215,-.

Umur penyadap pinus tidak berpengaruh secara nyata terhadap pendapatan rumah tangga. Meskipun tanda koefisien regresinya positif yang menunjukkan bahwa semakin tua, maka pendapatan rumah tangga semakin besar. Namun, hal tersebut tidak nyata secara statistik. Kondisi ini disebabkan usia penyadap yang relatif tua dan relatif seragam sehingga variasi usia tidak mempengaruhi pendapatan rumah tangga. Temuan tersebut berbeda dengan Prahasto (1988) yang menemukan hubungan negatif antara umur dengan pendapatan. Dimana semakin tua umur pesanggem akan menurunkan pendapatan yang diterima karena kemampuan fisik semakin menurun dan curahan tenaga kerja yang semakin menurun.

Jumlah anggota keluarga tidak secara nyata berpengaruh terhadap pendapatan keluarga. Kondisi ini dikarenakan sedikitnya anggota keluarga usia kerja yang turut membantu kepala keluarga mencari nafkah. Alasannya, mereka harus mengurus anak dan rumah tangga serta bersekolah.

Luas lahan tidak berpengaruh nyata terhadap pendapatan. Hal ini dikarenakan lahan yang dimiliki umumnya berupa lahan kering yang memiliki produktivitas rendah. Akibatnya, peningkatan luas lahan yang dimiliki tidak secara signifikan mempengaruhi pendapatan rumah tangga. Temuan ini berbeda dengan Prahasto (1988), dimana penambahan luas lahan akan meningkatkan pendapatan. Kondisi di 
daerah penelitian yang dilakukan Prahasto berbeda dengan lokasi kajian ini, dimana lokasi kajian tidak dilakukan pemanfaatan lahan secara optimal.

\section{KESIMPULAN DAN SARAN}

\subsection{Kesimpulan}

Berdasarkan hasil penelitian dan pembahasan dapat ditarik kesimpulan bahwa pendapatan rumah tangga penyadap getah pinus dipengaruhi secara signifikan oleh pendapatan di luar getah pinus, usia pohon pinus, dan produksi getah pinus. Peningkatan pendapatan di luar getah pinus, usia pohon dan produksi getah pinus akan secara nyata baik secara bersama-sama maupun tunggal meningkatkan pendapatan rumah tangga petani. Pendapatan rumah tangga petani penyadap getah pinus dapat ditingkatkan dengan meningkatkan pendapatan dari luar getah pinus dan peningkatan produksi getah pinus yang disertai dengan peningkatan harga getah pinus. Hal ini berimplikasi bahwa peningkatan kesejahteraan petani penyadap dilakukan dengan diversifikasi dan peningkatan sumber pendapatan di luar pinus, pengaturan umur pinus optimal dan kebijakan peningkatan produktivitas pohon pinus.

\subsection{Saran}

Peningkatan pendapatan petani di daerah sekitar hutan pinus dapat dilakukan dengan pemanfaatan hasil hutan non kayu seperti getah pinus. Peningkatan pendapatan masyarakat sekitar hutan pinus dilakukan dengan diversifikasi pendapatan rumah tangga di luar pinus dan peningkatan produktivitas getah pinus. Peningkatan produktivitas getah pinus dapat dilakukan dengan managemen hutan pinus, perbaikan varietas pohon pinus, dan perbaikan teknik penyadapan getah. Peningkatan produksi getah pinus akan meningkatkan pendapatan petani seiring 
dengan bertambahnya usia pohon pinus. Untuk itu perlu pula penelitian lanjutan umur optimal pohon pinus yang disadap dan teknik penyadapan pinus yang optimal.

Peningkatan pendapatan di luar pinus dilakukan dengan pengembangan usaha-usaha di luar penyadapan getah pinus (misalnya berdagang, beternak, berladang, dan lain-lain) karena secara nyata mampu meningkatkan pendapatan rumah tangga penyadap getah pinus dan mengurangi tekanan pada hutan pinus. Selain itu, perlu kebijakan peningkatan harga getah dan pengembangan lembaga semacam koperasi untuk meningkatkan kesejahteraan masyarakat.

\section{DAFTAR PUSTAKA}

Annonim. 1997. Pinus Andalan Kedua Sesudah Jati. Duta Rimba, 20 (3): 30—32.

Tim UGM. 2002. Penyusunan Rancangan Teknik Untuk Penelitian DAS Berpasangan di Gombong Jawa Tengah. Draft Laporan Akhir. Fakultas Teknologi Pertanian. Universitas Gadjah Mada. Yogyakarta.

Gujarati, D. 1979. Ekonometrika Dasar. Dialihbahasakan oleh Sumarno Zain. Penerbit Erlangga. Jakarta.

Jariah, N.A. 1998. Manfaat Sosial Ekonomi Penyadapan Pinus Terhadap Peningkatan Pendapatan Petani Penyadap: Studi Kasus di Desa Burat, RPH Gebang. BKPH Purworejo, KPH Kedu Selatan. Skripsi Sarjana. Jurusan Manajemen Hutan, Fakultas Kehutanan. Universitas Gadjah Mada. Yogyakarta.

Prahasto, H. 1988. Pengaruh Faktor Sosial Ekonomi Pesangem Terhadap Pendapatannya. Duta Rimba, 14 (91-92): 22—27.

Soedjono, S. 1992. Manfaat Ekonomi dan Sosial Penyadapan Getah Pinus. Bagian Perusahaan Kehutanan Negara. Duta Rimba, 18 (3): 149-150.

Suharlan, A, D. Herbagung, M.M. Riyadi. 1980. Hubungan Antara Produksi Getah Pinus Merkusii denga Luas Bidang Dasar, Tinggi Pohon, dan Jarak Tumbuh Relatif Antar Pohon. Laporan Penelitian Hutan. Bogor.

Tirtakusuma, R. 1978. Suatu Tinjauan dan Pendapatan Tentang Penyadapan Pinus Merkusii Jung et de Vriese. Perum Perhutani Jember. 
Lampiran 1. Hasil analisis regresi dengan Program SAS ETS ver 6.12

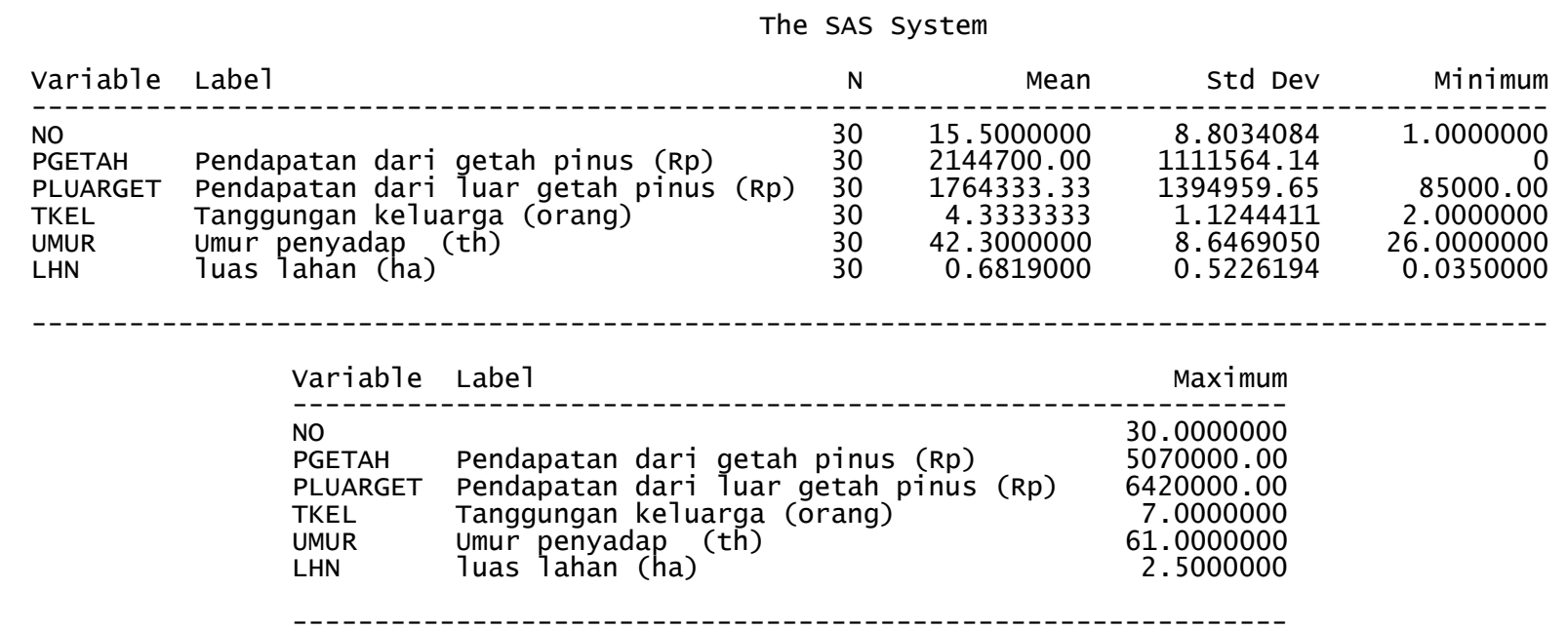

The SAS System

\begin{tabular}{llrrrr} 
Variable & Label & $\mathrm{N}$ & Mean & Std Dev & Minimum \\
\hline NO & & 30 & 15.5000000 & 8.8034084 & 1.0000000 \\
PGETAH & Pendapatan dari getah pinus (Rp) & 30 & 2144700.00 & 1111564.14 & 0 \\
PLUARGET & Pendapatan dari luar getah pinus (Rp) & 30 & 1764333.33 & 1394959.65 & 85000.00 \\
TANGKEL & Tanggungan keluarga (orang) & 30 & 4.333333 & 1.1244411 & 2.0000000 \\
UMUR & Umur penyadap (th) & 30 & 42.3000000 & 8.6469050 & 26.0000000 \\
LLAHAN & luas lahan (ha) & 30 & 0.6819000 & 0.5226194 & 0.0350000 \\
UPINUS & umur pinus (th) & 30 & 15.2333333 & 3.0477050 & 0 \\
PHNPINUS & jumlah pohon pinus (pohon) & 30 & 762.5666667 & 419.8740109 & 0 \\
QGETAH & produksi getah pinus (kg) & 30 & 2612.00 & 1306.08 & 800000.00 \\
TOINCOME & total pendapatan (Rp) & 30 & 3924733.33 & 1525404.34 & 8000
\end{tabular}




\begin{tabular}{llr} 
Variable Labe1 & Maximum \\
\hline NO & & 30.0000000 \\
PGETAH & Pendapatan dari getah pinus (Rp) & 5070000.00 \\
PLUARGET & Pendapatan dari luar getah pinus (Rp) & 6420000.00 \\
TANGKEL & Tanggungan keluarga (orang) & 7.0000000 \\
UMUR & Umur penyadap (th) & 61.0000000 \\
LLAHAN & luas 1ahan (ha) & 2.5000000 \\
UPINUS & umur pinus (th) & 18.0000000 \\
PHNPINUS & jumlah pohon pinus (pohon) & 2000.00 \\
QGETAH & produksi getah pinus (kg) & 6000.00 \\
TOINCOME & total pendapatan (Rp) & 7860000.00
\end{tabular}

The SAS system

Mode1: MODEL Karakter_sosek Dependent Variable: TOINCOME

total pendapatan (Rp)

Analysis of Variance

\begin{tabular}{|c|c|c|c|c|}
\hline Source & $\begin{array}{l}\text { Sum of } \\
\text { Squares }\end{array}$ & $\begin{array}{r}\text { Mean } \\
\text { Square }\end{array}$ & F value & Prob $>F$ \\
\hline $\begin{array}{l}\text { Mode1 } \\
\text { Error } \\
\text { C Tota1 }\end{array}$ & $\begin{array}{rl}6 & 5.4981309 \mathrm{E} 13 \\
23 & 1.2497585 \mathrm{E} 13 \\
29 & 6.7478894 \mathrm{E} 13\end{array}$ & $\begin{array}{l}9.1635514 \mathrm{E} 12 \\
543373271263\end{array}$ & 16.864 & 0.0001 \\
\hline $\begin{array}{l}\text { Root MSE } \\
\text { Dep Mean } \\
\text { C.V. }\end{array}$ & $\begin{array}{r}737138.56992 \\
3924733.33333 \\
18.78188\end{array}$ & $\begin{array}{l}\text { R-square } \\
\text { Adj R-sq }\end{array}$ & $\begin{array}{l}0.8148 \\
0.7665\end{array}$ & \\
\hline
\end{tabular}




\section{Parameter Estimates}

\begin{tabular}{|c|c|c|c|c|c|}
\hline Variable & DF & $\begin{array}{c}\text { Parameter } \\
\text { Estimate }\end{array}$ & $\begin{array}{r}\text { Standard } \\
\text { Error }\end{array}$ & $\begin{array}{c}\mathrm{T} \text { for } \mathrm{H} 0: \\
\text { Parameter }=0\end{array}$ & Prob $>|\mathrm{T}|$ \\
\hline $\begin{array}{l}\text { INTERCEP } \\
\text { UMUR } \\
\text { PROPLGET } \\
\text { TANGKEL } \\
\text { LLAHAN } \\
\text { UPINUS } \\
\text { QGETAH }\end{array}$ & $\begin{array}{l}1 \\
1 \\
1 \\
1 \\
1 \\
1 \\
1\end{array}$ & $\begin{array}{r}-4931502 \\
12467 \\
6926821 \\
-1776.383569 \\
-306365 \\
157769 \\
1215.731412\end{array}$ & $\begin{array}{l}1122770.7571 \\
22689.355835 \\
866090.05893 \\
157176.16407 \\
280995.93643 \\
56698.606050 \\
151.50477101\end{array}$ & $\begin{array}{r}-4.392 \\
0.549 \\
7.998 \\
-0.011 \\
-1.090 \\
2.783 \\
8.024\end{array}$ & $\begin{array}{l}0.0002 \\
0.5880 \\
0.0001 \\
0.9911 \\
0.2869 \\
0.0106 \\
0.0001\end{array}$ \\
\hline Variable & DF & \multicolumn{4}{|c|}{ Variable } \\
\hline $\begin{array}{l}\text { INTERCEP } \\
\text { UMUR } \\
\text { PROPLGET } \\
\text { TANGKEL } \\
\text { LLAHAN } \\
\text { UPINUS } \\
\text { QGETAH }\end{array}$ & $\begin{array}{l}1 \\
1 \\
1 \\
1 \\
1 \\
1 \\
1\end{array}$ & $\begin{array}{l}\text { Intercept } \\
\text { Umur penyadap } \\
\text { Kontribusi pe } \\
\text { Tanggungan ke } \\
\text { luas lahan (h } \\
\text { umur pinus (t } \\
\text { produksi geta }\end{array}$ & $\begin{array}{l}\text { (th) } \\
\text { luargatan luar } \\
\text { la) } \\
\text { h) } \\
\text { h pinus (kg) }\end{array}$ & etah pinus (\%) & \\
\hline
\end{tabular}


Lampiran 2. Data responden penelitian

\begin{tabular}{|c|c|c|c|c|c|c|}
\hline $\begin{array}{l}\text { No. } \\
\text { Resp. }\end{array}$ & Nama Resp. & Umur & Tangg Kel & Pendidikan & $\begin{array}{c}\text { Pekerjaan } \\
\text { Pokok }\end{array}$ & $\begin{array}{l}\text { Pekerjaan } \\
\text { Sambilan }\end{array}$ \\
\hline & & $\mathrm{Th}$ & (org) & & & \\
\hline 1 & Sutarman & 32 & 4 & SD & Petani & Penyadap Pinus \\
\hline 2 & Kasirun & 39 & 4 & SD & Petani & Penyadap Pinus \\
\hline 3 & Rusmadi & 47 & 3 & SD & Petani & Penyadap Pinus \\
\hline 4 & Sanrusdi & 38 & 3 & SD & Petani & Penyadap Pinus \\
\hline 5 & Sirun & 36 & 4 & SD & Petani & Penyadap Pinus \\
\hline 6 & Sikin & 27 & 2 & SD & Petani & Penyadap Pinus \\
\hline 7 & Warto & 37 & 4 & SD & Petani & Penyadap Pinus \\
\hline 8 & Yono & 47 & 4 & SD & Petani & Penyadap Pinus \\
\hline 9 & Supardi & 33 & 4 & SD & Petani & Penyadap Pinus \\
\hline 10 & suparlan & 39 & 5 & SD & Petani & Penyadap Pinus \\
\hline 11 & Kuswanto & 38 & 6 & SD & Petani & Penyadap Pinus \\
\hline 12 & Martawi & 61 & 7 & SD & Petani & Penyadap Pinus \\
\hline 13 & Mario Rejo & 50 & 5 & SD & Petani & Penyadap Pinus \\
\hline 14 & Sisri & 40 & 3 & SD & Penyadap pinus & Petani \\
\hline 15 & Karta & 41 & 6 & SD & KetuaRT/petani & Penyadap Pinus \\
\hline 16 & Sutaran & 52 & 5 & SD & Petani & Penyadap Pinus \\
\hline 17 & Sulasmi & 26 & 3 & SD & Petani & Penyadap Pinus \\
\hline 18 & San basir & 61 & 5 & SD/SR & Petani & Penyadap Pinus \\
\hline 19 & Santarmin & 35 & 3 & SD & Petani & Penyadap Pinus \\
\hline 20 & Minardi & 39 & 4 & SD & Petani & Penyadap Pinus \\
\hline 21 & Surat & 39 & 5 & SD & Penyadap & buruh bangunan \\
\hline 22 & Sutarso & 40 & 4 & $\mathrm{SD}$ & Petani & Penyadap Pinus \\
\hline 23 & Karso. W & 40 & 5 & SD & KetuaRW/petani & Penyadap Pinus \\
\hline 24 & Sarikun & 52 & 5 & SD & Dagang & Penyadap Pinus \\
\hline 25 & Rebin & 50 & 6 & SD & Petani & Penyadap Pinus \\
\hline 26 & Wardi & 40 & 4 & SD & Dagang & Penyadap Pinus \\
\hline 27 & Yatmo Miarso & 50 & 5 & SD & Petani & Penyadap Pinus \\
\hline 28 & Kasiman & 53 & 5 & SD & Petani & Penyadap Pinus \\
\hline 29 & Marno & 40 & 3 & SD & Petani & Penyadap Pinus \\
\hline 30 & Suji & 47 & 4 & SD & Petani & Penyadap Pinus \\
\hline
\end{tabular}

Cat:

Responden no 19 tidak menyadap lagi karena hak sadap diambilalih 
Tabel 2. Data responden penelitian (lanjutan)

\begin{tabular}{|c|c|c|c|c|c|c|c|}
\hline No & Pend getah & $\begin{array}{l}\text { Pend luar } \\
\text { getah }\end{array}$ & $\begin{array}{c}\text { Luas lahan } \\
\text { pert }\end{array}$ & Umur pinus & Jum Phn Pinus & Prod getah & Tot pend \\
\hline & $(\mathrm{Rp})$ & $(\mathrm{Rp})$ & (Ha) & (Th) & (pohon) & $(\mathrm{kg})$ & (Rp) \\
\hline 1 & 4080000 & 85000 & 0.5 & 15 & 1000 & 4800 & 4165000 \\
\hline 2 & 1200000 & 435000 & 0.54 & 16 & 500 & 1440 & 1635000 \\
\hline 3 & 2604000 & 2770000 & 0.75 & 18 & 1500 & 2880 & 5341000 \\
\hline 4 & 2040000 & 1400000 & 0.45 & 17 & 750 & 2400 & 3440000 \\
\hline 5 & 2490000 & 845000 & 0.45 & 15 & 750 & 3000 & 3335000 \\
\hline 6 & 3570000 & 200000 & 0.5 & 17 & 600 & 4200 & 3770000 \\
\hline 7 & 3060000 & 250000 & 0.035 & 16 & 700 & 3600 & 3310000 \\
\hline 8 & 3060000 & 1700000 & 0.5 & 15 & 750 & 3600 & 4760000 \\
\hline 9 & 840000 & 1064000 & 0.75 & 15 & 300 & 1440 & 1904000 \\
\hline 10 & 2040000 & 3080000 & 1 & 15 & 2000 & 2400 & 5120000 \\
\hline 11 & 540000 & 260000 & 0.25 & 15 & 580 & 720 & 800000 \\
\hline 12 & 5070000 & 518000 & 0.82 & 18 & 2000 & 6000 & 5588000 \\
\hline 13 & 1224000 & 3298000 & 2 & 15 & 500 & 1440 & 4522000 \\
\hline 14 & 954000 & 2270000 & 0.45 & 15 & 400 & 1440 & 3224000 \\
\hline 15 & 2028000 & 2950000 & 1 & 15 & 580 & 2400 & 4978000 \\
\hline 16 & 1824000 & 2450000 & 0.3 & 15 & 650 & 2160 & 4274000 \\
\hline 17 & 2580000 & 260000 & 0.5 & 15 & 750 & 3600 & 2948000 \\
\hline 18 & 2460000 & 1720000 & 1.25 & 15 & 600 & 3600 & 4360000 \\
\hline 19 & 0 & 2035000 & 0.75 & 0 & 0 & 0 & 2035000 \\
\hline 20 & 2700000 & 2900000 & 0.25 & 15 & 900 & 3600 & 5600000 \\
\hline 21 & 3060000 & 2100000 & 0.08 & 17 & 1000 & 3600 & 5160000 \\
\hline 22 & 3060000 & 1700000 & 0.58 & 17 & 600 & 3600 & 4760000 \\
\hline 23 & 1224000 & 1500000 & 1 & 16 & 750 & 1440 & 2724000 \\
\hline 24 & 1215000 & 6420000 & 0.4 & 15 & 630 & 1440 & 7860000 \\
\hline 25 & 1500000 & 2740000 & 0.75 & 15 & 600 & 1800 & 4231000 \\
\hline 26 & 1488000 & 3800000 & 0.05 & 15 & 600 & 1800 & 5288000 \\
\hline 27 & 960000 & 330000 & 0.602 & 15 & 500 & 1200 & 1290000 \\
\hline 28 & 1860000 & 600000 & 0.95 & 17 & 837 & 2160 & 2460000 \\
\hline 29 & 2550000 & 2150000 & 0.5 & 16 & 750 & 3000 & 4700000 \\
\hline 30 & 3060000 & 1100000 & 2.5 & 17 & 800 & 3600 & 4160000 \\
\hline
\end{tabular}

